\title{
ACCESSIBLE INFORMATION IN TOURISM: CASE OF CASUAL ITALIAN RESTAURANT
}

\author{
Novita Indah Mulyaningrum ${ }^{1}$, Nurul Sukma Lestari, Rachel Dyah Wiastuti \\ Hotel Management Department \\ Faculty of Economic and Communication, Bina Nusantara University, Jakarta, Indonesia \\ Corresponding email: novitaindahm.edu@gmail.com
}

\begin{abstract}
ABSTRAK:
Informasi adalah sekumpulan data yang dapat berguna bagi pengambilan keputusan dan saat ini menjadi sebuah bahan atau komoditas yang penting bagi semua golongan masyarakat, termasuk wisatawan. Accessible informationadalah informasi yang dapat dibaca atau diterima dan dipahami oleh individu atau kelompok, termasuk salah satunya adalah pengunjung restoran. Restoran adalah bagian dari sektor pendukung dalam pariwisata dan salah satu jenis restoran yang cukup banyak dikunjungi adalah casual Italian restaurant yang menyajikan makanan Italia dengan harga terjangkau. Tujuan penelitian ini adalah untuk mengidentifikasi penerapan kriteriaaccessible informationberdasarkan UNWTO pada 10casual Italian restaurant dari 5 brandyang berbeda di Jakarta.Penelitian ini menggunakan desain kualitatif dengan pendekatan eksploratif. Objek penelitian dipilih berdasarkan situs web Zomato yang diambil pada bulan Januari 2018. Data primer dikumpulkan melalui wawancara dan pengamatan langsung pada 10 casual Italian restaurant yang terbagi dalam 5 brand yang berbeda di Jakarta, yaitu; Domino's Pizza, Pizza Hut, Pizza Marzano, Popolamama dan The Kitchen by Pizza Hut. Data dianalisis dengan mengatur data, mendeskripsikannya ke dalam unit, mensintesis dan menyusun pola dari daftar pengamatan. Temuan menunjukkan penerapan accessible information dibagi berdasarkan tujuh kriteria;printed material, digital document, audio-visual content, website, mobile-apps, self service terminals-mobile devices dansignage. Hasil penelitian menunjukkan bahwa kriteria printed material dan signage telahbanyak diterapkan oleh mayoritascasual Italian restaurant, sementaraself-service terminals-mobile devicesbelum diterapkan. Implikasi studi bermanfaat dalam memberikan rekomendasi bagi casual Italian restaurantsupaya dapat memaksimalkan penerapan accessible information di restorannya untuk memenuhi kebutuhanberagam para tamu yang datang ke restoran mereka sehingga dapat memberikan kesempatan pada restoran tersebut untuk mempertahankan eksistensi dan mengembangkan usahanya.
\end{abstract}

Kata Kunci: Aksesibilitas, accessible information, accessible tourism, informasi, restoran 


\title{
National Conference of Creative Industry: \\ Sustainable Tourism Industry for Economic Development
}

Universitas Bunda Mulia, Jakarta, 5-6 September 2018

ISSN No:2622-7436

\begin{abstract}
:
Information is a collection of data that can be useful for decision making and currently an important material or commodity for all groups of people, including tourists.Accessible information is information that can be read or accepted and understood by individuals or groups, including a restaurant visitor. Restaurant is a part of supporting sector in tourism and one type of restaurant that quitevisited a lot is casual Italian restaurant which serves Italian food at affordable prices. This study aimed to identify the application of accessible information criteria by UNWTO in 10casual Italian restaurantsfrom 5 brands in Jakarta.This study used a qualitative method with an explorative approach. The object of the study was selected based on Zomato's website on January 2018. Primary data was collected through interviews and direct observation on 10 casual Italian restaurantsfrom 5 brands in Jakarta, namely; Domino's Pizza, Pizza Hut, Pizza Marzano, Popolamama and The Kitchen by Pizza Hut. Data were analyzed by arranging data, describing it into units, synthesizing and arranging patterns from the observation list. The findings showed that the application of accessible information is divided based on seven criterias; printed material, digital documents, audio-visual content, websites, mobile apps, self-service terminals-mobile devices and signage. The results showed that printed material and signage have been widely applied by the majority of casual Italian restaurants, while self-service terminals-mobile devices are not implemented yet. The implication's studyis providing recommendations for casual Italian restaurants to maximize the application of accessible information to meet the diverse needs of customer and giving opportunitiesto maintain restaurant existence and to expand its business.
\end{abstract}

Keywords: Accessibility,accessible information, accessible tourism, information, restaurant

\section{PENDAHULUAN}

Dalam dunia pariwisata, pemenuhan akan aspek-aspek pariwisata 4A yang terdiri dari Attraction (daya tarik), Accessibility (aksesibilitas), Amenities (fasilitas) dan Ancillary (kelembagaan) merupakan hal vital yang tidak dapat ditinggalkan (Ardika, 2003). Pada konsep 4A, aksesibilitas termasuk salah satu hal yang direkomendasikanuntuk dipenuhi dalam setiapfasilitas pariwisata (Ardika, 2003).Informasi adalah sekumpulan data yang dapat berguna bagi pengambilan keputusan dan saat ini menjadi sebuah bahan atau komoditas yang penting bagi semua golongan masyarakat, termasuk wisatawan (Sunaki,et.al., 2015).Perilaku pencarian informasi adalah suatu kegiatan atau aktivitas dari individu dalam mencari informasi yang dibutuhkan atau diinginkan dengan suatu tertentu (Yusup, 2010).Informasi mengenai aksesibilitas merupakan persyaratan mendasar bagi wisatawan dengan disabilitas. Apabila informasi memiliki kriteria accessible information sehingga dapat diakses oleh para wisatawan dengan disabilitas, maka para wisatawan tersebut dapat terlibat dalam pengambilan keputusan untuk memilih fasilitas pariwisata (Stumbo, 2005). Dalam accessible information, desain yang universal merupakan suatu kebutuhan karena desain ini merupakan sebuah pendekatan desain untuk menghasilkan fasilitas dan juga produk bagi semua orang (sebagai pengguna) secara umum, tanpa batasan fisik, rentang usia, dan juga jenis kelamin (Kusumarini \& Utomo, 2008). 


\section{National Conference of Creative Industry: \\ Sustainable Tourism Industry for Economic Development}

Universitas Bunda Mulia, Jakarta, 5-6 September 2018

ISSN No:2622-7436

Penerapan accessible information yang tepat sesuai dengan kriteria yang dipaparkan oleh UNWTO dapat berperan sebagaikunci keberhasilan berkomunikasi dalam pemberian informasipada tamu di setiap fasilitas pariwisata (UNWTO, 2016).

Salah satufasilitas penunjang dalam pariwisata adalah restoran sebagai salah satu wujud pemenuhan kuliner (Besra, 2012). Restoran sebagai usaha jasa penyediaan makanan dan minuman, turut menjadi salah satu faktor amenitas penting dalam pariwisata, yang juga memberikan kontribusi tinggi bagi pendapatan ekonomi di Indonesia. Data dari Badan Ekonomi Kreatif (Bekraf) Republik Indonesia mencatat, subsektor kuliner berkontribusi 41,4 persen dari total kontribusi perekonomian kreatif sebesar Rp 922 triliun pada 2016 dan memiliki pertumbuhan tertinggi di tahun 2017, yakni 9,23 persen.

Dari banyak jenis restoran, terdapat casual Italian restaurantyang cukup diminati oleh para tamu dan memiliki beberapa cabang yang tersebar di Jakarta. Konsep dari casual Italian restaurant ini adalah casual dining restaurant yang memiliki spesialisasi dalam menyajikan makanan Italia dengan harga yang terjangkau bagi para tamunya, dalam suasana makan yang santai dan juga waktu penyajian yang cukup singkat (fast food service). Sebagai salah satu jenis fasilitas pariwisata yang memiliki cukup peminat dengan outlet yang tersebar di seputaran Jakarta, maka sepatutnya pula casual Italian restaurant memenuhi kriteria accessible information yang direkomendasikan oleh UNWTO.Tujuan dari penelitian ini adalah mengidentifikasi penerapan kriteria accessible informationberdasarkan UNWTO pada casual Italian restaurant.

\section{TINJAUAN PUSTAKA}

\section{Accessible Tourism}

Accessible tourismadalah bentuk pariwisata yang melibatkan proses kolaboratif antara pemilik usaha pariwisata dengan pengunjung yang memiliki persyaratan akses yang terbatas, secara mobilitas, penglihatan, pendengaran dan kognitif supaya mampu melakukan aktivitas secara independen pada produk pariwisata dengan layanan dan lingkungan yang dirancang secara universal (Darcy\&Buhalis, 2011). Untuk menanggulangi adanya tantangan dalam accessible tourism, para pelaku industri pariwisata hendaknya dapat lebih fokus kepada; Physical accessibilitypada lingkungan dan jasa pelayanan wisata, Penyampaian informasi terkait dengan aksesibilitas danPresentasi dari accessible information (Pühretmai\&Buhalis, 2008). Aksesibilitas berperan penting dalammemberikan peluang pasar dan kebijakan pariwisata yang bertanggung jawab dan berkelanjutan, serta dalam strategi pengembangan bisnis (Moon, 2016).

\section{Accessible Information}

Accessible information adalah informasi yang dapat dibaca atau diterima dan dipahami oleh individu atau kelompok yang dimaksudkan (Marsay, 2017).Informasi yang dapat dipercaya dapat memberikan situasi khusus bagi para wisatawan dengan keadaan disabilitas dan menghindarkan mereka dari pengalaman buruk, serta memberi mereka waktu yang berharga selama berkunjung (Wee \& Sanmargaraja, 2016). Selain itu, dalam bentuk online, penyediaan informasi padaaccessible information tergantung pada berbagai jenis disabilitas, termasuk gangguan sensorik, motorik dan kognitif, dengan memanfaatkan beberapa jenis teknologi bantu, termasuk perangkat keras dan perangkat lunak seperti; pembaca layar, pengenalan suara, perangkat penunjuk dan 


\section{National Conference of Creative Industry: \\ Sustainable Tourism Industry for Economic Development}

Universitas Bunda Mulia, Jakarta, 5-6 September 2018

ISSN No:2622-7436

input alternatif, dan tampilan Braille. Hal ini untuk memungkinkan pengunjung dengan disabilitas dapat mengakses konten on-line (Pühretmai\&Buhalis, 2008).

Accessible information terdiri dari tujuh kriteria, yaitu; printed material, digital document, audio-visual content, website, mobile-apps, self service terminals-mobile devicesdan signage (UNWTO, 2016). Uraian dari accessible information tersebut adalah sebagai berikut:

Printed material.Printed material banyak digunakan dalam kegiatan promosi, pemberian informasi tentang layanan seperti menu atau prosedur dan isi lainnya. Ada empat hal utama yang digunakan pada printed material untuk meningkatkan kemudahan dalam membacanya, yaitu; tata letak, font, kontras dan warna, serta format alternatif (UNWTO, 2016).

Digital document.Digital document digunakan untuk mengirimkan sejumlah besar informasiyang penting di sektor pariwisata untuk memastikan orang tahu apa yang mereka unduh dan konten tersebutdapat digunakan dan diakses. Beberapa rekomendasi untuk digital document adalah; menerapkan gaya pada teks, menggunakan gambar atau piktogram, menggunakan format yang sudah ditentukan sebelumnya, mempertimbangkan untuk tidak menggunakan kolom, menggunakan teks atau simbol deskriptif, dan semua dokumen yang dapat diunduh harus memiliki ringkasan yang disediakan dalam HTML(UNWTO, 2016).

Audio-visual content.Dalam sektor pariwisata,audio-visual content dapat dibuat dalam banyak jenis, seperti video pengantar ke atraksi, panduan audio dan video atau papan display untuk memberikan informasi tentang sarana transportasi atau terminal penumpang. Teks dapat diberikan pada multimedia, sehingga dapat dipahami oleh semua pelanggan. Apabila keterangan tidak tersedia, maka transkrip dapat dicantumkan pada multimedia. Jendela pop-updapat dipertimbangkan untuk disertakan dalam video dengan penerjemah atau menyewa seorang penerjemah di sebuah acara. Versi deskripsi audio dari video dapat disertakan untuk membuatnya dapat diakses oleh pelanggan tunanetra. Video dapat dibagikan di tautan tertentu yang dapat ditonton dengan tampilan lain. Jika banyak dari target pasar dari bisnis pariwisata yang dikelola tidak berbicara dengan menggunakan bahasa yang tersedia pada video sebagai bahasa utama,konten dalam bahasa lain dapat diberikan bila memungkinkan(UNWTO, 2016).

Website.Kebutuhan akan informasi telah mendorong masyarakat untuk menempatkan media sebagai salah satu kebutuhan di dalam hidupnya. Hadirnya internet pada era globalisasi saat ini telah memunculkan media baru (new media) atau dikenal dengan sebutan media online (Pratama, 2017). Ada empat prinsip, yang harus diikuti dalam pengembangan setiap halaman web atau aplikasi web, yaitu: (1) Perceivable: dapat digunakan terlepas dari kemampuan pelanggan untuk melihat, mendengar atau menyentuh,(2) Operable: bentuk yang dapat digunakan, kontrol dan navigasi, (3)Understandable: konten dan antarmuka jelas dan mudah dimengerti, (4) Robust: konten dapat digunakan dengan andal oleh berbagai perangkat(UNWTO, 2016). Pada saat ini, website adalah alat penting untuk pariwisatakarena dapat memberikan informasi tentang produk, fasilitas, dan layanan. Aksesibilitas berfokus pada penyandang disabilitas (Henry, 2018).

Mobile-apps.Mobile-apps pariwisata adalah aplikasi perangkat lunak yang berjalan pada perangkat seluler. Hal ini secara bertahap telah dikembangkan pada website, terutama 


\section{National Conference of Creative Industry: \\ Sustainable Tourism Industry for Economic Development}

Universitas Bunda Mulia, Jakarta, 5-6 September 2018

ISSN No:2622-7436

untuk memberikan layanan seluler yang berbeda atau memberikan informasi tentang transportasi atau tujuan (UNWTO, 2016). Aksesibilitas seluler mengacu pada pembuatan situs web dan aplikasi yang lebih mudah diakses oleh penyandang disabilitas ketika mereka menggunakan ponsel dan perangkat lain (Henry, 2018).

Self-service terminals-mobile devices.Yang termasuk self-service terminals-mobile devicesdiantaranya adalah kios informasi, mesin penjual tiket, display informasi (misalnya,informasi penerbangan) dan sistem pembayaran kartu pelanggan, antara lain denganpoint-of-sale. Self service terminals-mobile devices harus memiliki beberapa kondisi sehingga orang dengan keadaan disabilitas masih bisa menggunakannya. Apabila mesin tersebut terletak di ketinggian, maka hendaknya masih dalam ketinggian yang dapat dijangkau oleh penyandang disabilitas sehingga mereka dapat menggunakannya, ruang kosong di dekat self service terminals-mobile devicesdapat digunakan untuk orang-orang dengan kursi roda, huruf braille, dan menambahkan panduan suara.(UNWTO, 2016).

Signage.Signage adalah alat yang memungkinkan pengunjung untuk mengorientasikan diri tanpa bantuan. Pengumuman harus bersifat visual dan dapat didengar. Layanan dan fasilitas yang dapat diakses harus ditandai dengan jelas dengan simbol yang mudah dimengerti dari ukuran dan warna yang sesuai dengan kontras dan latar belakang. Alarm kebakaran harus memancarkan sinyal visual dan akustik. Setiap kali papan nama ditempatkan di area yang mudah didekati, harus dipastikan tidak ada halangan untuk menjangkaunya.Format alternatif, seperti huruf dan Braille ada baiknya dipertimbangkan untuk dimasukkan (UNWTO, 2016).

\section{Casual Dining Restaurant}

Casual dining restaurant merupakan restoran yang dibuat untuk menarik pelanggan dari ekonomi menengah yang menyukai makan di luar dan tidak menginginkan suasana yang formal dan harga yang mahal, suasananya sederhana, santai, dan harga terjangkau (Gregoire\&Greathouse, 2010). Menurut klasifikasi restorannya, Italian restaurant termasuk dalam jenis Pizzeria yang memiliki menu utama pizza dan pasta (Marsum, 2005). Sedangkan, specialities restaurant adalah industri pelayanan jasa makanan dan minuman dengan menyediakan makanan khas dan diikuti sistem penyajian yang khas dari suatu negara tertentu (Soekresno, 2000).

\section{METODE PENELITIAN}

Metode yang digunakan dalam penelitian ini adalah metode kualitatif dengan pendekatan eksploratifuntuk mengetahui accessible informationpada casual Italian restaurant di Jakarta.. Penelitian kualitatif dilakukan karena "gaya" penelitian kualitatif berusaha mengkonstruksirealitas dan memahami maknanya, sehingga biasanya sangat memperhatikan proses,peristiwa dan otentisitas (Somantri, 2005). Observasi awal pada situs webwww.zomato.comdilakukan untuk melihat casual Italian restaurant sebagai objek penelitian. Tabel 1 menunjukkan informasi objek penelitian yang terdiri dari 5 brand casual Italian restaurant dengan 10 objek penelitian. Populasi didapatkan berdasarkan sejumlah kasus yang memenuhi kriteria yang ditentukan oleh peneliti (Mardalis, 2009). Data populasi didapatkan dari penelusuran pada situs webwww.zomato.com. Pemilihan sampel sebagai sebagian atau wakil dari yang diteliti 


\section{National Conference of Creative Industry: \\ Sustainable Tourism Industry for Economic Development}

Universitas Bunda Mulia, Jakarta, 5-6 September 2018

ISSN No:2622-7436

(Arikunto, 2010), menggunakan sistem pengambilan sampel secara convenience dengan berdasarkan kriteriamemiliki peminat yang umum, harga yang terjangkau, serta cabang yang tersebar di kota Jakarta. Nama-nama objek penelitianselanjutnya disingkat pada temuan dan analisis sesuai dengan singkatan yang telah disepakati. Pengumpulan data primer melalui observasi dan wawancara. Data sekunder dikumpulkan dari dokumentasi dan studi literatur seperti dokumen UNWTO, laporan UNWTO, jurnal penelitian, buku dan artikel lainnya.

Tabel 1. Daftar Casual Italian Restaurant di Jakarta

\begin{tabular}{|c|l|l|l|c|}
\hline No & Objek Penelitian & $\begin{array}{c}\text { Daftar } \\
\text { Singkatan }\end{array}$ & \multicolumn{1}{|c|}{ Alamat } & Area \\
\hline 1 & $\begin{array}{l}\text { Domino's Pizza } \\
\text { Indonesia }\end{array}$ & DP & $\begin{array}{l}\text { Jl. Kemanggisan Raya Blok B } \\
\text { No.3c }\end{array}$ & Jakarta Barat \\
\cline { 4 - 5 } & $\begin{array}{l}\text { Pl. Permata Hijau No.34 } \\
\text { Indonesia }\end{array}$ & PH & $\begin{array}{l}\text { Menara Cakrawala, Jl. M.H } \\
\text { Thamrin }\end{array}$ & Jakarta Selatan \\
\cline { 4 - 5 } & & $\begin{array}{l}\text { Mall Cibubur Junction, Jl. } \\
\text { Jambore No.1 }\end{array}$ & Jakarta Pusat \\
\hline 3 & Pizza Marzano & PM & Mall Grand Indonesia & Jakarta Pusat \\
\cline { 4 - 5 } & & Mall Central Park & Jakarta Barat \\
\hline 4 & Popolamama & PL & Mall Grand Indonesia & Jakarta Pusat \\
\cline { 4 - 5 } & $\begin{array}{l}\text { The Kitchen by } \\
\text { Pizza Hut }\end{array}$ & TK & Neo Soho Mall & Jakarta Selatan \\
\hline
\end{tabular}

Sumber:(www.zomato.com, 2018)

Pengamatan dilakukan dalam waktu dua bulan dari Januari 2018 hingga Februari 2018 pada 10 objek penelitian. Peneliti menghabiskan waktu 3 jam untuk mengamati setiap casual Italian restaurant. Observation checklist disiapkan dan digunakan sebagai panduan untuk mencakup semua kriteria accsessible informationdi bidang pariwisata. Observation checklist terdiri dari delapan bagian; (1) informasi umum tentang casual Italian restaurant, tanggal, waktu pengamatan, (2) observation checklistdan catatan printed material, (3) observation checklist dan catatan digital document, (4) observation checklistdan catatan audio-visual content, (5) observation checklist dan catatanwebsite, (6) observation checklist dan catatan mobile-apps, (7) observation checklistdan catatanself service terminal-mobile devices, (8) observation checklist dan catatan signage. Dokumentasi dilakukan bersamaan dengan observasi. Dokumentasi dilakukan untuk mengumpulkan foto yang diambil selama observasi yang mencakup semua kriteria accessible information dan keadaan umum dari masing-masing restoran.Analisis dilakukan pada saat observasi selesai dan semua delapan bagian daftar periksa diisi, bersama dengan semua data temuan dari dokumentasi. Data dianalisis secara sistematis dengan mengaturobservation checklist, catatan lapangan, gambar, dan materi lain seperti alat pemasaran dan informasi online. Melalui analisis ini, peneliti dapat menggambarkan accessible informationpada casual Italian restaurant. 


\section{HASIL PENELITIAN DAN PEMBAHASAN}

\section{Hasil Penelitian}

Hasil penelitian dijelaskan berupa ada atau tidaknya kriteria accessible information pada setiap casual Italian restaurant seperti yang tertera pada Tabel 2, untuk kemudian diuraikan secara terperincidan deskriptif dalam tujuh kriteria accessible information, yaitu; printed material, digital document, audio-visual content, website, mobile-apps, self service terminals-mobile devices dan signage. Setiap nama casual Italian restaurant akan disingkat mengacu pada Tabel 1.

Tabel 2. Hasil Observasi Umum Accessible Information

\begin{tabular}{|c|c|c|c|c|c|c|c|c|}
\hline No & Objek & $\begin{array}{c}\text { Printed } \\
\text { Material }\end{array}$ & $\begin{array}{c}\text { Digital } \\
\text { Document }\end{array}$ & $\begin{array}{c}\text { Audio- } \\
\text { visual } \\
\text { Content }\end{array}$ & Website & $\begin{array}{c}\text { Mobile- } \\
\text { apps }\end{array}$ & $\begin{array}{c}\text { Self } \\
\text { service } \\
\text { terminal- } \\
\text { mobile } \\
\text { devices }\end{array}$ & Signage \\
\hline 1 & DP & V & V & V & V & V & X & V \\
\hline 2 & PH & V & V & V & V & X & X & V \\
\hline 3 & PM & V & V & V & V & X & X & V \\
\hline 4 & PL & V & X & V & V & X & X & V \\
\hline 5 & TK & V & X & V & X & X & X & V \\
\hline
\end{tabular}

Keterangan: $(\mathrm{V})=$ ada; $(\mathrm{X})=$ tidak ada

Sumber: Peneliti,(2018)

Pada Tabel 2, dapat dilihat bahwa setiap casual Italian restaurant telah memiliki kriteria accessible information pada printed material, audio-visual content dan juga signage. Sedangkan 2 casual Italian restaurant terlihat tidak memiliki digital document (PL dan TK), 1 casual Italian restaurant tidak memilikiwebsite (TK), 4 casual Italian restaurant tidak memilikimobile-apps (PH,PM.PL, TK), serta keseluruhan tidak memiliki self service terminal-mobile devices.

Dalam penerapan printed material,untuk layout, font, kontras, serta warna pada printed material yang dimiliki oleh DP, PH, PM, PL dan TK, cukup memenuhi kriteria dari accessible information. Printed material yang dimiliki masih dalam tahap mudah untuk dibaca secara langsung. Akan tetapi, beberapa printed material yang dimiliki oleh PH dan PM, terutama yang memiliki kerjasama promosi dengan Bank, terlalu banyak tulisan dengan ukuran font yang terlalu kecil (kurang dari 12pt), sehingga agak menyulitkan untuk dibaca. Selain itu, meskipun mudah dilihat karena menampilkan gambar, single card menu milik TK, memiliki jenis huruf yang 'fancy' pada judul menu, sehingga agak sulit untuk dibaca sambil lalu. Sementara untuk PM, pada buku menunya, terlalu menampilkan banyak tulisan, sehingga buku menu terkesan 'penuh' dan sulit untuk dibaca. Pada setiap masing-masing casual Italian restaurant, bahasa yang digunakan rata-rata menggunakan Bahasa Inggris baik untuk penamaan menu, maupun deskripsi bahan makanannya, kecuali $\mathrm{PH}$ yang menggunakan Bahasa Indonesia.

Dalam penerapan digital document,pada DP, PH dan PMterdapat penawaran untuk menjadi mendaftar mengikutimailinglist mereka, sehingga setiap yang telah mendaftar, akan dikirimkan penawaran khusus beserta sejumlah dokumen yang dapat didownload. 


\section{National Conference of Creative Industry: \\ Sustainable Tourism Industry for Economic Development}

Universitas Bunda Mulia, Jakarta, 5-6 September 2018

ISSN No:2622-7436

Sementara itu, untuk PL dan TK, tidak ada informasi yang tersaji mengenai pendaftaran mailinglist, maupun download langsung dokumen promosi pada website.

Dalam penerapan audio-visual content, DP merupakan salah satu yang cukup memenuhi kriteria. Selain tampilan iklan yang bergerak dan diberi suara, disitu juga terdapat deskripsi dari iklan yang sedang berlangsung. Selain itu, DP juga memiliki papan penunjuk antrean yang berguna untuk melihat sampai dimana pesanan kita diproses. Sementara untuk PH, PM dan PL, ada beberapa outlet yang tidak menampilkan audio-visual content, dan beberapa tidak memiliki suara. Sedangkan untuk TK, yang ditampilkan hanya visual, berupa gambar-gambar 'seni' buatan tangan tanpa suara.

Dalam penerapan website, tampilan pada website DP, PH, PM memenuhi kriteria pokok dari accessible information yaitu perceiveable, operable, understandable dan robust. Sedangkan untuk PL, ada beberapa perintah pada website yang tidak operable. Sementara itu, TK tidak tersebutkan memiliki website resmi dan hanya tercantum pada beberapa social media.

Dalam penerapan mobile-apps, hanya DP yang memenuhi kriteria karena satusatunya yang dapat diunduh pada mobile-apps. Tampilan mobile-apps mudah untuk dioperasikan dan mudah untuk pemilihan menunya.

Dalam penerapan self-service terminal-mobile devices, sesuai dengan hasil observasi, kriteria ini belum dimiliki oleh seluruh casual Italian restaurant yang dijadikan obyek penelitian.

Dalam penerapan signage, sebagian besar signage menggunakan nama sesuai dengan nama restaurantdengan huruf yang mudah terbaca dan memiliki kontras warna yang tidak menyakiti mata, serta menyertakan pictogram. Tidak ada format braille pada signage masing-masing casual Italian restaurant. Simbol-simbol homogen ditemukan pada beberapa restaurant untuk menunjukkan keberadaan toilet maupun tempat mencuci tangan.

\section{Pembahasan}

Pada DP, PL, PM dan TK, ditemukan adanya penggunaan Bahasa Inggris pada setiap menu dan deskripsinya. Hal initerjadi karena casual Italian restaurant ini menganggap bahasa tersebut sudah merupakan bahasa yang universal di zaman sekarang, walaupun keberadaannya adalah di Indonesia. Oleh karena itu, maka penggunaan Bahasa Inggris dirasa cukup wajar. Akan tetapi, penggunaan Bahasa Inggris tanpa ada terjemahan sama sekali dalam Bahasa Indonesia, bisa jadi memberikan hambatan informasi tersendiri bagi pengunjung yang memang tidak dapat berbahasa Inggris.

Selain itu, untuk TK, yang sebenarnya merupakan pembaharuan konsep dari PH, tidak memiliki kriteria vital yaitu website. Sementara, walaupun TK disebut sebagai salah satu anak perusahaan $\mathrm{PH}$, namun tidak ada penyebutan maupun penjelasan mengenai outlet dan menu yang ditawarkan pada website PH. Tentunya hal ini menjadi suatu hambatan informasi tersendiri bagi TK.

Pada penggunaan mobile-apps, hanya DP saja yang telah menerapkannya. Tentunya hal ini dapat menjadi nilai tambah tersendiri bagi DP karena apbila ada pengunjung restoran yang berminat untuk memesan DP, namun terhalang disabilitas secara fisik sehingga tidak dapat bepergian sendiri, maka DP masih dapat dipesan secara mandiri tanpa harus datang ke restoran dan hanya memanfaatkan fasilitas mobile-apps saja. 


\section{National Conference of Creative Industry: \\ Sustainable Tourism Industry for Economic Development}

Universitas Bunda Mulia, Jakarta, 5-6 September 2018

ISSN No:2622-7436

Pada DP, PH, PL, PM dan TK, tidak ditemukan sama sekali adanya self service terminal-mobile devices. Hal ini terjadi karena casual Italian restaurant tersebut masih mengutamakan interaksi secara langsung antara pengunjung restoran dengan pegawai restoran. Akan tetapi, hal ini dapat menjadi hambatan tersendiri apabila ada pengunjung restoran yang memiliki disabilitas tuna rungu ataupun tuna wicara. Hambatan tersebut dapat terjadi apabila pegawai restoran tidak dapat berinteraksi dengan baik secara verbal dengan pemilik disabilitas.

\section{KESIMPULAN DAN IMPLIKASI}

Hasil penelitian menunjukkan bahwa kriteria printed material dan signage telahbanyak diimplementasikan oleh mayoritascasual Italian restaurant, meskipun belum terlalu komprehensif seperti detail yang direkomendasikan oleh UNWTO. Hal ini bisa saja berpengaruh pada orang yang terkendala dari segi bahasa, maupun yang memiliki disabilitas lainnya, untuk tidak dapat mengetahui informasi casual Italian restaurant tersebut secara maksimal. Selain itu,self-service terminals-mobile devices belum diimplementasikan pada semua casual Italian restaurant. Implikasi dari studi ini untuk selanjutnya adalah adanya pemenuhan kriteria lain dari accessible information, yaitu contoh;self-service terminals-mobile devicessehingga dapat memberikan kesempatan pada restoran untuk mempertahankan eksistensi dan mengembangkan usahanya.. Saran yang dapat diusulkan bagi bisnis casual Italian restaurant ini, dengan adanya pemenuhan self-service terminal-mobile devices, dapat lebih memaksimalkan manfaat bagi tamu dengan disabilitas, khususnya tuna rungu ataupun tuna wicara untuk dapat melakukan pesanan secara langsung, tanpa harus melakukan banyak interaksi dengan pegawai restoran. Masukan lain yang terkait adalahdikarenakan banyak dari casual Italian restaurant ini yang telah memiliki website, maka di masa mendatang dapat lebih memaksimalkan fungsi website yang telah ada dengan penambahan teknoligi screen reader yang sangat berguna bagi pelanggan dengan disabilitas motorik maupun penglihatan. Bagi penelitian selanjutnya, diharapkan adanya penelitian lebih lanjut untuk accessible information pada sektor pendukung pariwisata lainnya.

\section{DAFTAR PUSTAKA}

Agmasari, Silvita.(2018).Industri Kuliner, Penopang Tertinggi Perekonomian Kreatif di Indonesia.Diakses pada 24 Juli 2018, dari https://travel.kompas.com/read/2018/02/06/185000027/industri-kulinerpenopang-tertinggi-perekonomian-kreatif-di-indonesia

Ardika, I Wayan (Penyunting).(2003). Pariwisata Budaya Berkelanjutan: Refleksi dan Harapan di Tengah Perkembangan Global. Denpasar: Program Studi Magister (S2) Kajian Pariwisata, Program Pascasarjana Universitas Udayana.

Arikunto, Suharsimi. (2010). Prosedur Penelitian: Suatu Pendekatan Praktik. Jakarta:Rineka Cipta

Besra, Eri. (2012). Potensi Wisata Kuliner Dalam Mendukung Pariwisata di Kota Padang. Jurnal Riset Akuntansi dan Bisnis, Vol. 12 No.1/Maret 2012. Sumatra Utara 


\section{National Conference of Creative Industry: \\ Sustainable Tourism Industry for Economic Development}

Universitas Bunda Mulia, Jakarta, 5-6 September 2018

ISSN No:2622-7436

Darcy, S. \& Buhalis, D. (2011). Introduction: From disabled tourists to accessible tourism. In D. Buhalis \& S. Darcy (Eds.), Accessible tourism: Concepts and issues (pp. 1-20), Bristol: Channel View.

Dinas Pariwisata Kutai Timur.(2017).Konsep Dasar dan Penerapan A4 Dalam Dunia Pariwisata.Diakses $\quad$ pada $24 \quad$ Juli darihttps://dinaspariwisata.kutaitimurkab.go.id/news/6-konsep-dasar-danpenerapan-a4-dalam-dunia-pariwisata

Fadiyah, MWS.(2018).Industri Makanan dan Minuman Menjadi Sektor Andalan di 2018.Diakses pada 24 Juli 2018, dari https://bisnis.tempo.co/read/1058746/industri-makanan-dan-minumanmenjadi-sektor-andalan-di-2018

Gregoire, Mary B and Greathouse, Karen R. (2010).Research Contribution. Who WillDirect Hospital Foodservice Departments in the Future?.Journal ofFoodservice Management \& Education, Volume 4(1):1 - 4.

Henry, S. L. (2018). Web Accessibility Initiative. Diakses dari W3C: https://www.w3.org/WAI/

Kusumarini, Yusita\&Utomo, Tri N.P. (2008). "Pendekatan Desain Universal (DesainInklusif) Dalam Perancangan Interior. Evaluasi karya desain: Sayembara

Internasional Desain Kamar Mandi "Accessible Restroom” 2007." ITB Journal of Visual Art and Design. Vol.2 no.1. Bandung.

Mardalis. (2009). Metode Penelitian. Jakarta: Bumi Aksara

Marsay, S. (2017). Accessible Information: Specification. England: NHS

Marsum, W. (2005). Restoran dan Segala Permasalahannya. Edisi 4. Yogyakarta: Andi

Moon, B.(2016).Tourism for All.Diakses pada 15 April 2018, dari http://wtd.unwto.org/content/officialmessages-world-tourism-day-0

Pratama, Ari Gusrendra. (2017). Peran Media Online Dalam Memenuhi Aksesibilitas Informasi Publik Bagi Penyandang Disabilitas di Kota Bandung: Studi KasusPada Media Online www.bbc.com. Diploma Thesis:UIN Sunan Gunung Djati. Bandung

Pühretmai, Franz and Buhalis, Dimitrioas.(2008). Accessible Tourism Introduction to the Special Thematic Session.Annals of Tourism Research, Vol.35(1)

Soekresno. (2000).Management Food and Beverage, Service Hotel. Jakarta: PT. Gramedia Pustaka Umum

Somantri, Gumilar Rusliwa.(2005). Memahami Metode Kualitatif. MAKARA, Sosial Humaniora, Vol.9, No.2, Desember 2005:57-65

Stumbo, N.J.\&Pegg, S.(2005). Travellers and Tourists with Disabilities: A Matter of Prioritiesand Loyalties. Tourism Review International, 8 (3): pp. 195-209 


\section{National Conference of Creative Industry: \\ Sustainable Tourism Industry for Economic Development}

Universitas Bunda Mulia, Jakarta, 5-6 September 2018

ISSN No:2622-7436

Sunaki, Fadia, Rukiyah dan Lydia Christiani. (2015). Kebutuhan dan Perilaku PencarianInformasi Wisatawan di Tourist Information Center Pemuda Semarang. Jurnal Ilmu Perpustakaan, Vol. 4 No. 2:April 2015. Semarang

Wee, S., \& Sanmargaraja, S. (2016). Accessible Information Required by the Independent Disabled Tourist:A Mini Review. Australian Journal of Basic and Applied Sciences, 65-70.

World Tourism Organization. (2016). Recommendations on Accesible information in Tourism. Madrid: UNWTO.

Yusup, Pawit M. (2010). Teori dan Praktik Penelusuran Informasi: information retrieval.Jakarta: Kencana Prenada Media

\section{BIODATA}

Pada penelitian ini, penulis satu adalah Novita Indah Mulyaningrum, SST. Par, M.Par yang merupakan Faculty Memberdi Universitas Bina Nusantara dan menyelesaikan pendidikan D4 Hotel Management serta S2 Magister Pariwisata di Sekolah Tinggi Pariwisata Trisakti. Dapat berkorespondensi melalui novitaindahm.edu@gmail.com. Penulis dua adalah Nurul Sukma Lestari, SST.Par, MM., CHE yang merupakan Faculty Member di Universitas Bina Nusantara dan menyelesaikan pendidikanHotel Management di Sekolah Tinggi Pariwisata Trisakti, serta S2 Sumber Daya Manusia di Universitas Sahid. Dapat berkorespondensi melalui nurul.lestari@binus.edu. Penulis tiga adalah Rachel Dyah Wiastuti, SST.Par, MM., M.Par yang merupakan Faculty Member di Universitas Bina Nusantara dan menyelesaikan pendidikan D4 Hotel Administration di Sekolah Tinggi Pariwisata Bandung, S2 Pariwisata di Sekolah Tinggi Pariwisata Trisakti serta S2 Pemasaran Pariwisata di Universitas Sahid. Dapat berkorespondensi melalui rwiastuti@binus.edu. 